\title{
Development of Analytical Methods for the Direct Determination of Silver in Plutonium-Thorium and Uranium-Thorium-Based Fuels Using GFAAS
}

\author{
Neelam Goyal*, P. J. Purohit, Santosh Kumar Gupta, and S. V. Godbole \\ Radiochemistry Division, Bhabha Atomic Research Centre
}

Trombay, Mumbai 400 085, India

\begin{abstract}
Studies on the atomization of silver in Pu+Th and U+Th matrices were carried out. The effect of matrix composition and its concentration on Ag absorbance using graphite furnace atomic absorption spectrometry (GFAAS) was investigated. These studies showed that the absorbance signal observed for Ag in a mixed matrix was enhanced compared to that observed for a pure thorium matrix, but it is poorer than in matrix-free solutions. The enhancement was found to be more pronounced in a $\mathrm{Pu}+\mathrm{Th}$ than in U+Th matrix. The difference in the behaviors of $\mathrm{Ag}$ atomization efficiency in these matrices is explained on the basis of change of $\mathrm{pO}_{2}$ during dissociation of plutonium nitrate and uranyl nitrate at the atomization temperature of silver. Accumulation of $\mathrm{Pu}$ and $\mathrm{U}$ with successive loading in the graphite atomizer did not have any additional effect on the ana-
\end{abstract}

\section{INTRODUCTION}

Due to the increasing availability of ${ }^{239} \mathrm{Pu}$ as a by product of spent U-bearing nuclear fuels and also due to the attractive fissile behavior of ${ }^{239} \mathrm{Pu}$, plutonium-bearing nuclear fuel materials are becoming promising substitutes to ${ }^{235} \mathrm{U}$-enriched fuels in thermal and fast reactors. The strict quality control on the purity of these materials has to be assured during the fuel fabrication

\footnotetext{
* Corresponding author.

E-mail: neelam@barc.gov.in
}

lyte absorbance. Based on these investigations, two analytical methods using GFAAS were developed for the direct determination of $\mathrm{Ag}$ in the $0.1-4.0 \mathrm{ppm}$ range on the basis of $20 \mathrm{mg} / \mathrm{mL}$ each of (Pu+Th) and (U+Th) solution with $3 \% \mathrm{Pu}$ and $3 \% \mathrm{U}$, respectively.

The performance of these methods was evaluated by analyzing synthetic samples of Pu+Th and $\mathrm{U}+\mathrm{Th}$. The values obtained for synthetic samples agreed favorably with the added concentrations. It is of significance to note that the present method gains in importance due to its ability to determine silver without the need for a prior chemical separation of the Pu+Th and U+Th matrices. The analytical procedure developed could be applied for the rapid analyses of Advance Heavy Water Reactor (AHWR) sample solutions without pre-treatment of the samples such as separation and pre-concentration of the matrix.

process. The Advance Heavy Water Reactor (AHWR), therefore, was proposed to have ${ }^{235} \mathrm{U},{ }^{233} \mathrm{U}$, and ${ }^{239} \mathrm{Pu}$. The AHWR (1) was conceived to use fuel comprised of solid solutions of plutonium-thorium and uranium-thorium in the form of their oxides. Of these, plutonium-thorium fuel shall have $2.5 \%$ and $4 \% \mathrm{Pu}$ and uranium-thorium fuel shall contain $3 \%$ and $3.75 \%$ of uranium in AHWR.

Recent Compact High Temperature Reactor (CHTR) designs generally make use of fuel kernels surrounded by four successive layers of low-density pyrocarbon, highdensity pyrocarbon, silicon carbide and high-density pyrocarbon, with silicon carbide being the main barrier for the metallic species. These so-called TRISO fuel particles retain quite effectively most of the important fission products like cesium, iodine, xenon, and krypton up to temperatures of $1000^{\circ} \mathrm{C}$, but the release of silver seems to present a major problem. Despite the low fission yield of the stable ${ }^{109} \mathrm{Ag}$ $\left(0.03 \%\right.$ for $\left.{ }^{235} \mathrm{U}\right)$ and its low conversion rate of $0.1 \%$ to ${ }^{110 \mathrm{~m}} \mathrm{Ag}$ by neutron capture, the latter is considered as one of the key fission products. Total Ag concentration, therefore, should be monitored in AHWR fuel since its isotope ${ }^{110 \mathrm{~m}} \mathrm{Ag}$, with a relatively long half-life of 253 days, has a high $\gamma$-ray dose rate (2).

The determination of silver in the presence of various nuclear materials such as $25 \% \mathrm{Pu}$ in (Pu-U) (3), U (4), Th (5) were reported earlier from our laboratory. However, the application of GFAAS for determining $\mathrm{Ag}$ has not been investigated in the presence of $\mathrm{Pu}+\mathrm{Th}$ and U+Th matrices. Reports are also available for silver determination in wine (6), urine (7), geological and related materials (8-9), teeth (10), precious metals (11), blood (12), steel (13), environmental samples (14), and water samples (15) by flame and flameless AAS.

In addition to AAS, other analytical techniques are also in use to determine silver in polymeric samples by absorption, mass and X-ray spectrometry (16); seawater (17) by sensitive sector field inductively coupled plasma mass spectrometry (SF-ICP-MS); edible oils by inductively coupled plasma optical emis- 
sion spectrometry (ICP-OES) (18); and milk by ICP-MS (19). The determination of $\mathrm{Ag}$ in $(\mathrm{Pu}+\mathrm{Th})$ and $(\mathrm{U}+\mathrm{Th})$ matrices has not yet been reported in the literature.

The present study examines the change in the analyte absorbance signals with a change in matrix composition of $\% \mathrm{Pu} / \mathrm{Pu}+\mathrm{Th}$ and $\% \mathrm{U} / \mathrm{U}+\mathrm{Th}$ and the concentration of $\mathrm{Pu}+\mathrm{Th}$ and $\mathrm{U}+\mathrm{Th}$ using GFAAS analysis. These studies were then utilized for the direct determination of ppm amounts of silver in $\mathrm{Pu}+\mathrm{Th}$ and $\mathrm{U}+\mathrm{Th}$ matrix with $3 \% \mathrm{Pu}$ and $3 \% \mathrm{U}$, respectively, employing GFAAS. The mechanism of release of gaseous atoms from the solid lattice in GFAAS has previously been investigated by thermodynamicskinetics approaches (20). It was noted that though the nitrate solution of either $\mathrm{Ag}$ or $\mathrm{Pu}+\mathrm{Th} / \mathrm{U}+\mathrm{Th}$ was loaded, nitrates get converted to oxides of $\mathrm{Ag}, \mathrm{Pu}+\mathrm{Th}$ and $\mathrm{U}+\mathrm{Th}$. Ag has to be released from the $\mathrm{Pu}+\mathrm{Th}$ and $\mathrm{U}+\mathrm{Th}$ oxide lattices.

A comparison of the analyte atom density in pure and in matrix oxides was used to understand the matrix effect on the Ag absorbance signal. An enhancement was observed in the $(\mathrm{Pu}+\mathrm{Th}) /(\mathrm{U}+\mathrm{Th})$ matrix as compared to a pure thorium matrix. The enhancement was found to be more pronounced in the $\mathrm{Pu}+\mathrm{Th}$ than in the $\mathrm{U}+\mathrm{Th}$ matrix and this was correlated with the release of oxygen during dissociation of the matrices (3).

\section{EXPERIMENTAL}

The two different instruments were used for the determination of $\mathrm{Ag}$ in the Pu+Th and $\mathrm{U}+\mathrm{Th}$ matrices:

\section{Instrumentation}

To analyze Pu-bearing samples, a Varian Techtron Model AA-6 atomic absorption spectrometer (Varian Techtron, Australia), equipped with a carbon rod atomizer (CRA-63, Mini Massmann) and BC-6 background corrector, operating in peak height measurement mode, was used. The AAS unit was adapted for radioactive work by modifying the modular setup by placing the isolated atomizer in a glove box environment and details have been given earlier (21).

To analyze $\mathrm{U}$ and Th samples, a computer-controlled GBC-906 atomic absorption spectrometer, equipped with a GF 3000 graphite furnace atomizer and programmable sample dispenser, was used for the determination of $\mathrm{Ag}$ (GBC Scientific Equipment Pty., Ltd., Australia). The graphite furnace was pyrolytically coated and atomization was secured from the sample loaded inside the graphite atomizer. The atomizer was covered with a shield made of Perspex ${ }^{\circledR}$ which can be displaced when access to the atomizer was necessary. Containment of uranium-thorium fumes was ensured through the adequate exhaust system provided around the atomizer. The atomizer unit exhaust was connected to a glove box exhaust system and was described earlier in detail (22). Our laboratory previously reported the details of the preparation of plutonium ( $40 \mathrm{mg} / \mathrm{mL}$ ) (23), uranium $(40 \mathrm{mg} / \mathrm{mL})$, and thorium (200 mg/mL) solutions (24) along with the procedure adopted.

Silver working solutions were prepared by appropriate dilution of the standard stock solutions $(1 \mathrm{mg} / \mathrm{mL} \mathrm{Ag}$ in $5 \%$ nitric acid, (VHG Labs, Manchester, NH, USA).

The instrumental parameters for $\mathrm{Ag}$, using both of the instruments, are given in Table I.

Argon gas of $99.995 \%$ purity was used as the purge gas.

To study the matrix effect, a standard of mid-range concentration was prepared for Ag with varying amounts each of $\mathrm{Pu}+\mathrm{Th}$ and $\mathrm{U}+\mathrm{Th}$ matrix ranging from $0-40$ $\mathrm{mg} / \mathrm{mL}$ (zero concentration corresponding to $0 \mathrm{mg} / \mathrm{mL} \mathrm{Th}$ ).

\section{Atomic Spectroscopy $\bigcirc$ Vol. 32(5), Sept./Oct. 2011}

To study the effect of varying amounts each of plutonium and uranium in the $\mathrm{Pu}+\mathrm{Th}$ and $\mathrm{U}+\mathrm{Th}$ matrices, mid-range concentration standards were prepared for $\mathrm{Ag}$ with $\mathrm{Pu}$ and $\mathrm{U}$ ranging from $0-10 \%$, with an overall matrix concentration fixed at $20 \mathrm{mg} / \mathrm{mL}$. After optimizing the matrix portion for direct determination of $\mathrm{Ag}$ in the $\mathrm{Pu}+\mathrm{Th}$ and $\mathrm{U}+\mathrm{Th}$ matrices, a series of standard solutions were prepared each containing $20 \mathrm{mg} / \mathrm{mL} 3 \% \mathrm{Pu} / \mathrm{Pu}+\mathrm{Th}$ (0.6 mg Pu/mL + 19.4 mg Th/mL) and $3 \% \mathrm{U} / \mathrm{U}+\mathrm{Th}(0.6 \mathrm{mg} \mathrm{U} / \mathrm{mL}+$ $19.4 \mathrm{mg} \mathrm{Th} / \mathrm{mL}$ ) and graded concentrations of $\mathrm{Ag}$ in the range of $0-100 \mathrm{ng} / \mathrm{mL}$ from the $\mathrm{Ag}$ stock solution.

In the absence of certified reference materials with these types of matrices, three synthetic samples of $(\mathrm{Pu}+\mathrm{Th})$ and $(\mathrm{U}+\mathrm{Th})$ were prepared similarly. These were used as reference samples for obtaining precision and to validate the method developed here.

The fundamental conditions of GFAAS analysis (such as temperature and time durations at the preatomization and atomization steps) were investigated in order to identify the optimum conditions for obtaining stable and sensitive atomic absorbance signals for $\mathrm{Ag}$ in $\mathrm{Pu}+\mathrm{Th}$ and $\mathrm{U}+\mathrm{Th}$ as well as in the matrix-free solution. The detailed procedure adopted here was similar to that followed earlier for trace metal analysis of Ag in plutoniumuranium (3), and for 3\% $\mathrm{Pu}+\mathrm{Th}$ and in uranium-thorium for $3 \% \mathrm{U}+\mathrm{Th}$

\section{TABLE I}

Instrumental Parameters for Ag with CRA-63 and GF-3000 AAS

\begin{tabular}{lr}
\hline Wavelength & $328.1 \mathrm{~nm}$ \\
Spectral Bandwidth & $0.5 \mathrm{~nm}$ \\
Lamp Fill Gas & $\mathrm{Ne}$ \\
Lamp Current & $5 \mathrm{~mA}$ \\
Gas Used & $\mathrm{Ar}$ \\
Flow rate & $6 \mathrm{~L} / \mathrm{min}$ \\
\hline
\end{tabular}


(24). Ag absorbance was monitored as a function of (a) matrix concentration in the range $0-40 \mathrm{mg} / \mathrm{mL}$ each of Pu+Th and U+Th using fixed analyte concentrations; (b) matrix composition on a fixed concentration of Ag and varying plutonium/uranium proportions in the range $0-10 \% \mathrm{Pu}$ and $\mathrm{U}$. Characteristic concentration was obtained for $\mathrm{Ag}$ by analyzing two sets of standards, i.e., one each in 3\% Pu+Th and $3 \% \mathrm{U}+\mathrm{Th}$ with graded portions of Ag.

\section{RESULTS AND DISCUSSION}

In GFAAS, atomization of an analyte in the presence of a complex matrix (such as $\mathrm{Pu}, \mathrm{U}$, and Th) is the result of an interaction of analyte-matrix, analyte-carbon, or carbon-matrix. It was reported that the atomization behavior of silver changed in the presence of $\mathrm{Pu} / \mathrm{U} / \mathrm{Th}$ matrices (3-5). It was also reported that the absorbance signals for Ag was reduced significantly in uranium (4) and thorium (5) compared to that observed in aqueous solution, while the absorbance signal showed an enhancement when plutonium was added to the uranium solution (3). These studies led us to investigate the effect of matrix concentration as well as matrix composition on analyte absorbance for the mixed matrix of $\mathrm{Pu}+\mathrm{Th}$ and $\mathrm{U}+\mathrm{Th}$ solutions.
An investigation of the GFAAS measurement parameters (preatomization temperature, atomization temperature, and time) is very important for achieving precise and sensitive atomic absorbance measurements. The pre-atomization temperature is critical in the case of silver since $\mathrm{AgNO}_{3}$ dissociates to silver oxide $\left(\mathrm{Ag}_{2} \mathrm{O}\right)$ at $300{ }^{\circ} \mathrm{C}$, which decomposes immediately, and $\mathrm{Ag}$ atomization takes place at $877^{\circ} \mathrm{C}$ (25). For optimization of the GFAAS measurement parameters, effects of the pre-atomization and atomization temperature on the absorbance were investigated on GF 3000 in the temperature range of $300-700{ }^{\circ} \mathrm{C}$ for $\mathrm{Ag}$ in $20 \mathrm{mg} / \mathrm{mL}$ thorium matrix. As seen from Table II, the $\mathrm{S} / \mathrm{N}$ ratio was maximum at $600{ }^{\circ} \mathrm{C}$. The effect of the atomization temperature on the absorbance of Ag was similarly investigated over a temperature range 2100 to $2500{ }^{\circ} \mathrm{C}$. A constant and maximum absorbance was obtained at an atomization temperature of 2300 to $2400{ }^{\circ} \mathrm{C}$. Based on these observations, pre-atomization and atomization temperatures and time durations were selected for Ag using the proposed procedures which were $600{ }^{\circ} \mathrm{C} / 30 \mathrm{~s}$ and $2300{ }^{\circ} \mathrm{C} / 0.3 \mathrm{~s}$, respectively. The results of the pre-atomization/ atomization studies for thorium are listed in Table II.

\section{Effect of Matrix Composition}

The effect of matrix composition was studied by varying the plutonium/uranium percentage in the thorium matrix from $0-10 \%$, keeping the total matrix concentration as $20.0 \mathrm{mg} / \mathrm{mL}$ at $0.04 \mu \mathrm{g} / \mathrm{mL} \mathrm{Ag}$. It was observed that with an increase in plutonium composition in the $\mathrm{Pu}+\mathrm{Th}$ matrix, Ag absorbance increased by $15 \%$ with $2 \% \mathrm{Pu}$ as compared to the pure Th solution $(0 \% \mathrm{Pu})$; then it remained unaffected with an increase in $\mathrm{Pu}$ at $2-4 \%$ concentration in the $\mathrm{Pu}+\mathrm{Th}$ matrix. The effect of uranium in the thorium matrix was seen on Ag absorbance by varying the U concentrationfrom $0-10 \%$, keeping the total matrix concentration as $20 \mathrm{mg} / \mathrm{mL}$. It was observed that with an increase in uranium concentration up to $2 \%$ in the U+Th matrix, the Ag absorbance increased by $12 \%$ as compared with Th alone, and then onwards remained unaffected in the range of $2-4 \% \mathrm{U}$. The expected percentage of $\mathrm{Pu} / \mathrm{U}$ in AHWR fuel is 2-4\%. Hence, in further studies, the $\mathrm{Pu} / \mathrm{U}$ composition was kept at $3 \% \mathrm{Pu} / 3 \% \mathrm{U}$ in the mixed matrix. However, beyond 4 to $10 \%$, the rise was insignificant for both of the mixed matrices. The results are shown in Table III.
TABLE II

Optimized Experimental Parameters for $\mathrm{Ag}$ at $0.04 \mu \mathrm{g} / \mathrm{mL}$ in $\mathrm{Th}$

\begin{tabular}{ccc|ccc}
\hline \multicolumn{2}{c|}{$\begin{array}{c}\text { Pre-atomization Step } \\
\text { Temperature at } 2300^{\circ} \mathrm{C}\end{array}$} & \multicolumn{3}{|c}{$\begin{array}{c}\text { Atomization Step } \\
\text { Temperature at } 600{ }^{\circ} \mathrm{C}\end{array}$} \\
\hline $\begin{array}{c}\text { Temp. } \\
\left({ }^{\circ} \mathrm{C}\right)\end{array}$ & & Matrix & Absorbance & \multicolumn{2}{c}{$\begin{array}{c}\text { Temp. } \\
\left({ }^{\circ} \mathrm{C}\right)\end{array}$} \\
\hline 300 & 0.008 & 0.238 & 2100 & 0.008 & 0.193 \\
400 & 0.002 & 0.256 & 2200 & 0.002 & 0.227 \\
500 & 0.002 & 0.260 & 2300 & 0.002 & 0.281 \\
600 & 0.002 & 0.281 & 2400 & 0.004 & 0.280 \\
700 & 0.004 & 0.230 & 2500 & 0.004 & 0.265 \\
\hline
\end{tabular}

TABLE III

Effect of Increase of $\% \mathrm{Pu}$ and $\% \mathrm{U}$ on Ag Absorbance in Mixed Matrices

\begin{tabular}{c|cc}
\hline $\begin{array}{c}20 \mathrm{mg} / \mathrm{mL} \text { Matrix } \\
\text { With Varying }\end{array}$ & \multicolumn{2}{|c}{ Absorbance } \\
Ag/Pu+Th & $\mathrm{Ag} / \mathrm{U}+\mathrm{Th}$ \\
Composition of $\% \mathrm{Pu} / \mathrm{U}$ & $0.04 \mu \mathrm{g} / \mathrm{mL}$ & $0.04 \mu \mathrm{g} / \mathrm{mL}$ \\
\hline Aqu. (matrix-free) & 0.74 & 0.74 \\
0 & 0.314 & 0.314 \\
2 & 0.370 & 0.350 \\
3 & 0.370 & 0.355 \\
4 & 0.370 & 0.354 \\
5 & 0.363 & 0.360 \\
10 & 0.370 & 0.364 \\
\hline
\end{tabular}


Our laboratory reported earlier (24) that with a progressive increase in \%U/U+Th matrix, the $\mathrm{Mg}$ absorbance is suppressed; while in present studies, Ag absorbance enhanced with the addition of uranium in a thorium matrix. This can be explained on the basis of uranium and thorium chemistry. With thorium, the matrix-carbon interaction competes with the analyte-carbon interaction since thorium has a higher carbon affinity and preferentially forms a uniform stable $\mathrm{ThC}_{2}$ layer. Unlike in the case of $\mathrm{Mg}$ (24) in U+Th, wherein $0.1 \mathrm{mg} / \mathrm{mL}$ matrix was used, i.e., $0.097 \mathrm{mg} / \mathrm{mL}$ Th. Carbon of the graphite tube was not fully utilized with each loading of the (U+Th) matrix. Thorium, due to repeated loading of the mixed (U+Th) matrix, was all used to keep making the stable $\mathrm{ThC}_{2}$ layer; and the $\mathrm{UO}_{2}\left(\mathrm{NO}_{3}\right)_{4}$ of the mixed matrix was free and forms carbide through oxide. The $\mathrm{UC} / \mathrm{UC}_{2}$ remained on the surface. It dissolves with $0.1 \mathrm{MHNO}_{3}$ from loading of the next aliquot and forms uranyl nitrate again. Hircq (27) reported the re-dissolution of $\mathrm{UC} / \mathrm{UC}_{2}$ from the next loading of the nitrate solution in the atomizer using the following equation:
This uranyl nitrate on dissociation gives free $[\mathrm{O}]$ and in turn suppresses $\mathrm{Mg}$ absorbance (24). Thermo-gravimetric (26) studies on $\mathrm{ThO}_{2}-2 \% \mathrm{U}_{3} \mathrm{O}_{8}$ granules also showed a continuous decrease in weight in the temperature range of $400-1500{ }^{\circ} \mathrm{C}$. The weight loss was mainly attributed to a release of oxygen from $\mathrm{U}_{3} \mathrm{O}_{8}$. Dissolution of thoria essentially requires $\mathrm{HF}$ along with $\mathrm{HNO}_{3}$. Hence, it did not dissolve in $\mathrm{HNO}_{3}$ during the next aliquot loading.

In the present studies, 200 times more matrix was loaded every time in comparison to the $\mathrm{Mg}$ (24) determination. A uniform stable $\mathrm{ThC}_{2}$ layer is formed during the initial stage itself in the atomizer due to the availability of more thorium, and $\mathrm{Pu} / \mathrm{U}$ is trapped in the stable lattice of $\mathrm{ThC}_{2}$. The thoria lattice is very stable and has a defect-free structure due to its stoichiometric composition. The presence of $\mathrm{U} / \mathrm{Pu}$ atoms leads to lattice defects in thoria. The presence of these lattice defects assists faster diffusion (28) of silver in $\mathrm{Pu}+\mathrm{Th}$ and $\mathrm{U}+\mathrm{Th}$ oxides compared to the thorium carbide/ oxide layer. These changes increased the mobility of the Ag atoms and showed an increase in Ag

$\mathrm{UO}_{2}\left(\mathrm{NO}_{3}\right)_{2} \cdot 6 \mathrm{H}_{2} \mathrm{O}_{(\mathrm{s})} \rightarrow \mathrm{UO}_{3(\mathrm{~s})} \rightarrow \mathrm{U}_{3} \mathrm{O}_{8(\mathrm{~s})} \rightarrow \mathrm{UO}_{2(\mathrm{~s})} \rightarrow \mathrm{UC} / \mathrm{UC}_{2}$

$\stackrel{\mathrm{HNO}_{3}}{\mathrm{UO}_{2}\left(\mathrm{NO}_{3}\right)_{2} \cdot 6 \mathrm{H}_{2} \mathrm{O}_{(\mathrm{s})}} \rightarrow \underset{\mathrm{UO}_{3(\mathrm{~s})} \rightarrow \mathrm{U}_{3} \mathrm{O}_{8(\mathrm{~s})}}{\mathrm{HNO}_{3}} \rightarrow \mathrm{UO}_{2(\mathrm{~s})} \rightarrow \mathrm{UC} / \mathrm{UC}$

TABLE IV Variation of Absorbance With Matrix Concentration on Ag Absorbance in 3\%Pu+97\% Th and 3\%U+97\% Th

\begin{tabular}{c|cc|cc}
\hline $\begin{array}{c}\text { Matrix } \\
\text { Conc. } \\
(\mathrm{mg} / \mathrm{mL})\end{array}$ & \multicolumn{2}{|c|}{$\begin{array}{c}\text { Absorbance } \\
\text { Matrix Blank }\end{array}$} & $\begin{array}{c}\text { Ag } \\
(0.04 \mu \mathrm{g} / \mathrm{mL})\end{array}$ & \multicolumn{2}{|c}{ Absorbance 3\%U+Th } \\
Matrix Blank & $\begin{array}{c}\mathrm{Ag} \\
(0.04 \mu \mathrm{g} / \mathrm{mL})\end{array}$ \\
0.0 & 0.002 & 0.740 & 0.00 & 0.740 \\
1.0 & 0.031 & 0.590 & 0.012 & 0.582 \\
2.0 & 0.033 & 0.572 & 0.005 & 0.454 \\
5.0 & 0.036 & 0.446 & 0.006 & 0.405 \\
10.0 & 0.037 & 0.388 & 0.007 & 0.410 \\
20.0 & 0.036 & 0.386 & 0.022 & 0.426 \\
30.0 & 0.023 & 0.361 & 0.012 & 0.419 \\
40.0 & 0.024 & 0.357 & 0.022 & 0.406 \\
\hline
\end{tabular}

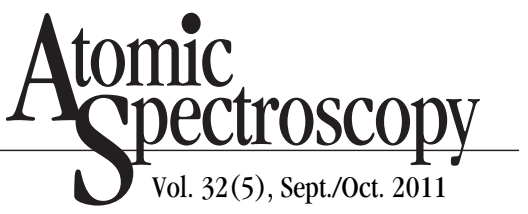

absorbance in the presence of $\mathrm{Pu} / \mathrm{U}$ compared to thorium matrix alone.

\section{Effect of Matrix Concentration}

A systematic reduction in the absorbance signal was reported (4) for Ag with a progressive increase in $\mathrm{U}$ concentration up to $20 \mathrm{mg} / \mathrm{mL}$. A study on the atomization of $\mathrm{Ag}$ in matrix-free solutions as well as in the $(\mathrm{Pu}+\mathrm{Th}) /(\mathrm{U}+\mathrm{Th})$ matrix was, therefore, carried out. The variation obtained in the GFAAS absorbance signal of $\mathrm{Ag}$ as a function of an increase in matrix concentration ranging from $0-40 \mathrm{mg} / \mathrm{mL}$ is shown in Table IV. As can be seen, a suppression in the absorbance signal was observed with an increase in matrix concentration ranging from $0-40 \mathrm{mg} / \mathrm{mL}$. This indicates suppressive interference on $\mathrm{Ag}$ due to the presence of $(\mathrm{Pu}+\mathrm{Th}) /(\mathrm{U}+\mathrm{Th})$ matrix. To meet the Ag expected specification limit of 2-10 ppm for AHWR fuel, the matrix concentration was kept at $20.0 \mathrm{mg} / \mathrm{mL}$ for further studies. The suppression in Ag absorbance with $20.0 \mathrm{mg} / \mathrm{mL}$ $(\mathrm{Pu}+\mathrm{Th}) /(\mathrm{U}+\mathrm{Th})$ is almost 2.5 times that of the matrix-free solution.

All experimental parameters were freshly optimized for each of the 3\% Pu+Th and 3\%U+Th matrix. The maximum $\mathrm{S} / \mathrm{N}$ ratio was obtained and the parameters are listed in Table V.

TABLE V

Optimized Experimental Parameters of Graphite Furnace Atomizer for $\mathrm{Ag}$ in (3\%Pu+Th)/(3\%U+Th)

\begin{tabular}{ccc|cc}
\hline \multicolumn{3}{c|}{$\begin{array}{c}\text { For 3\%U+Th } \\
\text { GF-3000 }\end{array}$} & \multicolumn{2}{c}{ For 3\%PU+Th } \\
CRA-63 \\
\hline Temp. & \multicolumn{2}{c|}{ Time (s) } & Temp. & Time \\
$\left({ }^{\circ} \mathrm{C}\right)$ & Ramp & Hold & $\left({ }^{\circ} \mathrm{C}\right)$ & $(\mathrm{s})$ \\
\hline 80 & 5 & 10 & 150 & 30 \\
120 & 10 & 10 & 300 & 30 \\
300 & 5 & 10 & 700 & 40 \\
600 & 0.2 & 10 & 2300 & 3 \\
2300 & 0.9 & 0.3 & & \\
20 & 14.5 & 10.0 & & \\
\hline
\end{tabular}


Peak profiles were plotted at $0.04 \mu \mathrm{g} / \mathrm{mL} \mathrm{Ag}$ in the absence and presence of matrix (3\%U+Th and Th alone) at $20 \mathrm{mg} / \mathrm{mL}$ matrix concentration (see Figure 1).

It was observed that the peak profile broadens. Peak height and peak area reduces in the presence of the matrices as compared to matrix-free solutions. An enhancement of $\sim 12 \%$ in peak profile of the (3\%U+Th) matrix was obtained as compared with the Th matrix alone. To analyze the Pu-bearing samples, a Varian Techtron Model AA-6 atomic absorption spectrometer, equipped with a carbon rod atomizer (CRA-63, Mini Massmann, which is not computer-controlled), was used; hence, peak profile data for $(3 \% \mathrm{Pu}+\mathrm{Th})$ could not be obtained.

Successive loadings of (Pu+Th) and (U+Th) solutions leads to matrix build-up inside the graphite atomizer. However, this build-up of matrix did not have any significant effect on the $\mathrm{Ag}(0.04 \mu \mathrm{g} / \mathrm{mL})$ absorbance with repetitive loadings of the $20.0 \mathrm{mg} / \mathrm{mL}$ mixed matrix on the same atomizer. The absorbance remained constant with repetitive loadings of the sample for 100 atomization cycles.

Measurements of atomic absorption signals for Ag were carried out over a wide range of concentrations using standard solutions for these matrices The linear analytical ranges in the presence and absence of the matrices were obtained and are shown in Figure 2.

Suppression in absorbance was observed for $\mathrm{Ag}$ in (3\% Pu+Th) and in $(3 \% \mathrm{U}+\mathrm{Th})$ matrices as compared to the aqueous matrix. The influence of the mixed matrices on silver atomization behavior is also compared in Figure 2 with the reported data on the Th (5) matrix. The Ag sensitivity is poorer in mixed matrices in comparison to the pure nitrate solution, but better than that in pure thorium nitrate solution. The enhancement was found to be more pronounced in the $(\mathrm{Pu}+\mathrm{Th})$ than in the $(\mathrm{U}+\mathrm{Th})$ matrix as compared to Th matrix alone. It was reported earlier (3) that the presence of the plutonium matrix significantly altered the situ- ation for Ag atomization and the Ag absorbance was improved as compared with a pure uranium matrix. This can be explained on the basis of thermal decomposition of $\mathrm{Pu}\left(\mathrm{NO}_{3}\right)_{4}$ which led to a marginal change in the oxygen-to-metal ratio as compared with $\mathrm{UO}_{2}\left(\mathrm{NO}_{3}\right)_{2}$ and, hence, Ag atomization was not affected in the Pu matrix. A similar explanation is also valid for the present studies with $(\mathrm{Pu}+\mathrm{Th})$ as compared to $(\mathrm{U}+\mathrm{Th})$.

These results necessitated the development of two independent analytical methods. Studies were carried out using a $3 \% \mathrm{Pu} / \mathrm{Pu}+\mathrm{Th}$ and a $3 \% \mathrm{U} / \mathrm{U}+\mathrm{Th}$ matrix. The analytical ranges and the lowest absolute amounts determined for each of the matrices of $3 \% \mathrm{Pu} /(\mathrm{Pu}+\mathrm{Th})$ and 3\%U/(U+Th) are given in Table VI. The limits of quantitative determination obtained in the present work for $3 \% \mathrm{Pu} /(\mathrm{Pu}+\mathrm{Th})$ and $3 \% \mathrm{U} /(\mathrm{U}+\mathrm{Th})$ along with the reported data for Ag in the Th matrix are also included in the Table VI. The present values for $\mathrm{Ag}$ in the mixed matrices are lower by a factor of 2 than those

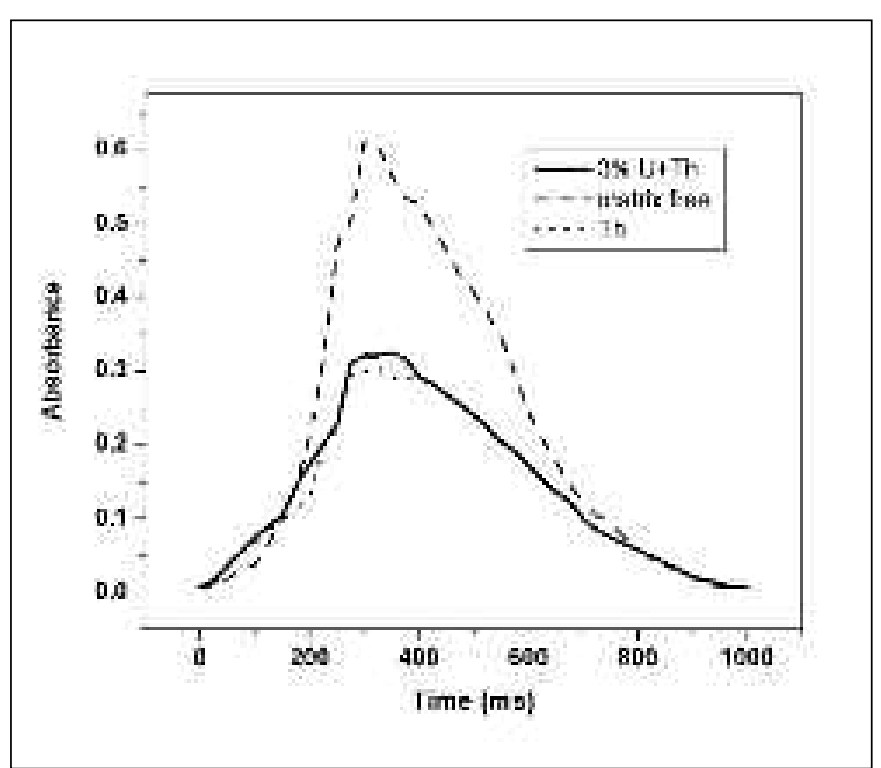

Fig. 1. Peak profile variation at $0.04 \mu \mathrm{g} / \mathrm{mL} \mathrm{Ag}$ in the absence and presence of matrix ( $3 \% U+T h$ and Th alone) keeping a total matrix concentration of $20 \mathrm{mg} / \mathrm{mL}$.

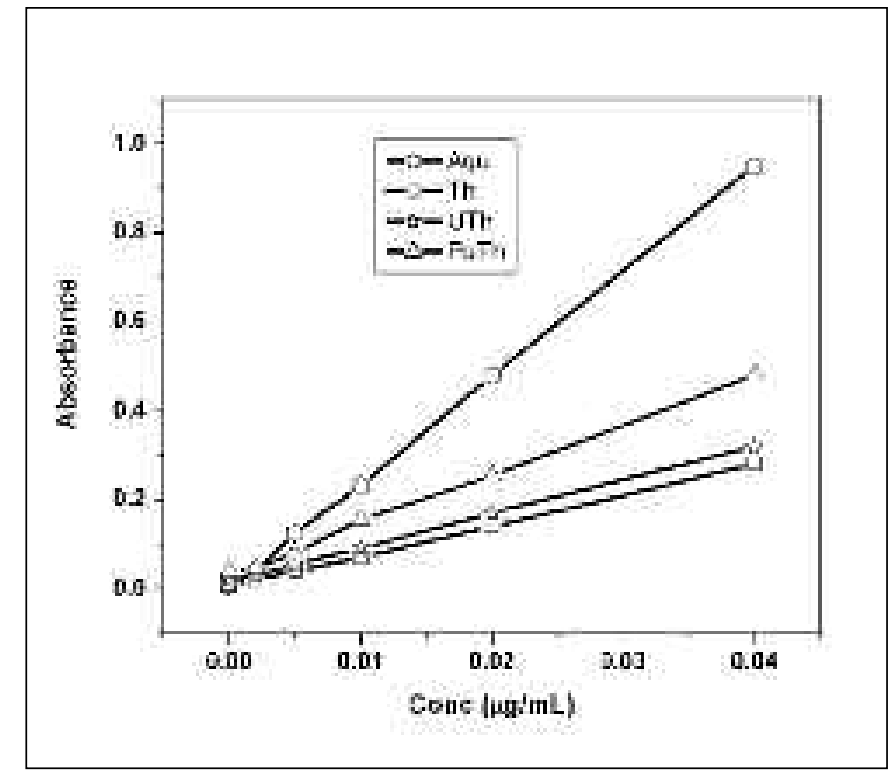

Fig. 2. Analytical curves for Ag in aqueous, Th, (3\%U+Th) and $(3 \% P u+T h)$, keeping a total of $20 \mathrm{mg} / \mathrm{mL}$ matrix concentration. 
reported for the Th matrix. The characteristic concentration values obtained for $\mathrm{Ag}$ in the $3 \% \mathrm{Pu} /(\mathrm{Pu}+\mathrm{Th})$ and $3 \% \mathrm{U} /(\mathrm{U}+\mathrm{Th})$ matrices as evaluated from the calibration plots are also shown in Table VI. The corresponding characteristic concentration values obtained in the reported data for aqueous (3) and thorium (5) matrix solutions are also included in Table VI. Silver showed a reduction in its absorbance to varying degrees in the presence of the $3 \% \mathrm{Pu} /(\mathrm{Pu}+\mathrm{Th})$ and $3 \% \mathrm{U} /(\mathrm{U}+\mathrm{Th})$ matrices in comparison to matrixfree solution.

Using the standardized procedure, three synthetic samples were analyzed. The results obtained from the analysis of these synthetic samples with $(3 \% \mathrm{Pu}+97 \% \mathrm{Th})$ and (3\%U+97\% Th) are shown in Table VII. The replicate analyses of the synthetic samples showed the precision of the method to be better than $8 \%$ RSD.

\section{CONCLUSION}

In this work, accurate and precise methods were developed for the direct determination of $\mathrm{Ag}$ in nuclear grade $3 \% \mathrm{Pu} /(\mathrm{Pu}+\mathrm{Th})$ and $3 \% \mathrm{U} /(\mathrm{U}+\mathrm{Th})$ oxide by graphie furnace atomic absorption spectrometry (GFAAS). The effect of matrix composition was studied and an increase in Ag absorbance of 15\% and $12 \%$ was obtained with (3\% Pu+Th) and (3\%U+Th) matrix, respectively, as compared with $\mathrm{Th}$ matrix alone.

The Ag absorbance remained unaffected with an increase in $\mathrm{Pu} / \mathrm{U}$ concentration ranging from $2-4 \%$ mixed matrix. The expected percentage of $\mathrm{Pu} / \mathrm{U}$ in Advance Heavy Water Reactor (AHWR) fuel is $2-4 \%$. The variation in the GFAAS absorbance signal of Ag as a function of increase in matrix concentration in the range $0-40 \mathrm{mg} / \mathrm{mL}$ was studied. Based on the data, determination of $\mathrm{Ag}$ at the $0.1 \mathrm{ppm}$ level is possible in the presence of $100 \mu \mathrm{g}$ amounts of matrix; however, it is necessary to have matching standards and sample compositions as regards the matrix concentration.

Since (Pu+Th) and (U+Th) oxides are refractory in nature, their lattices affect the atomization of silver. These nuclear materials are highly radioactive and highly toxic, and adequate suction was provided by the instrumentation for containment and to remove any toxic vapors from the glove box.

\section{ACKNOWLEDGMENT}

The authors are grateful to Dr. Ashok Goswami, Head, Radiochemistry Division, for his keen interest and constant encouragement in the course of this work.

Received June 2, 2011.

Table VI

Analytical Results for Determination of Ag in $\mathrm{Pu}+\mathrm{Th}$ and $\mathrm{U}+\mathrm{Th}$ Matrices and Characteristic Concentrations of $\mathrm{Ag}$ in (Pu+Th) and (U+Th) and in Aqueous Th Matrix

\begin{tabular}{|c|c|c|c|c|c|c|c|}
\hline $\begin{array}{l}\text { Linear analytical range } \\
\text { in } 3 \% \mathrm{Pu} /(\mathrm{Pu}+\mathrm{Th}) \text { and } \\
3 \% \mathrm{U} /(\mathrm{U}+\mathrm{Th}) \text { matrix }\end{array}$ & \multicolumn{3}{|c|}{$\begin{array}{l}\text { Limit of Quantitative } \\
\text { Determination } \\
(\mathrm{pg})\end{array}$} & \multicolumn{4}{|c|}{$\begin{array}{l}\text { Characteristic } \\
\text { Concentrations }\end{array}$} \\
\hline $0.002-0.08 \mu \mathrm{g} / \mathrm{mL}$ & $\begin{array}{l}3 \% \mathrm{Pu} / \\
(\mathrm{Pu}+\mathrm{Th})\end{array}$ & $\begin{array}{l}3 \% \mathrm{U} / \\
(\mathrm{U}+\mathrm{Th})\end{array}$ & $\begin{array}{l}100 \% \\
\text { Th (5) }\end{array}$ & $\begin{array}{l}\text { Aqu. } \\
\text { (3) }\end{array}$ & $\begin{array}{l}100 \% \\
\text { Th (5) }\end{array}$ & $\begin{array}{l}3 \% \mathrm{Pu} / \\
(\mathrm{Pu}+\mathrm{Th})\end{array}$ & $\begin{array}{r}\text { 3\%U/ } \\
(\mathrm{U}+\mathrm{Th})\end{array}$ \\
\hline $0.1-4.0 \mathrm{ppm}^{*}$ & 10 & 10 & 20 & 0.2 & 0.55 & 0.52 & 0.53 \\
\hline
\end{tabular}

*Based on $100 \mu \mathrm{g}$ of Pu+Th and $\mathrm{U}+\mathrm{Th}$ in $5-\mu \mathrm{L}$ solution.

${ }^{* *}$ Characteristic concentration is defined as the concentration corresponding to an absorbance of 0.0044 .

TABLE VII

Results of Analysis of Three Synthetically Prepared Samples for the Determination of $\mathrm{Ag}$ at ppm Levels in $\mathrm{Pu}+\mathrm{Th}$ and $\mathrm{U}+\mathrm{Th}$ Matrices

\begin{tabular}{c|ccc|c}
\hline \multirow{2}{*}{ Sample No. } & \multicolumn{2}{|c|}{ Concentration of Spike (ppm) } & \% RSD \\
& Added & \multicolumn{2}{c}{ Obtained } \\
\hline 1. & 0.8 & 0.77 & 0.775 & 8 \\
2. & 1.5 & 1.51 & 1.45 & 7 \\
3. & 2.5 & 2.34 & 2.35 & 4 \\
\hline
\end{tabular}




\section{REFERENCES}

1. R. K. Sinha and Anil Kakodkar, Nuclear Engineering and Design 236, 683 (2006).

2.. E. Friedland, N.G. van der Berg, J.B. Malherbe, J.J. Hancke, J. Barry, E. Wendler, and W. Wesch, J. Nuclear Materials 410, 24 (2011).

3. Neelam Goyal, Paru J. Purohit, A.G. Page, and M.D. Sastry, Fr. Z. Anal. Chem. 354, 311 (1996).

4. Neelam Goyal, P. J. Purohit, A.R. Dhobale, B. M. Patel, A.G. Page, and M.D.Sastry, J. Anal. At. Spectrometry 2, 459, 1987.

5. S.K. Thulasidas, Madhuri J. Kulkarni, N.K. Porwal, A.G. Page, and M.D. Sastry, Anal. Lett. 21, 265 (1988).

6. S.L.C. Ferreira, A. S. Souza, G. C. Brandao, H. S. Ferreira, W.N.L.S. dos Santos, M. F. Pimentel, and M.G.R. Vale, Talanta 74 (4), 699 (2008).

7. J. Flanjak and A. E. Hodda, Anal. Chim. Acta 207, 283 (1988).

8. P. Liang, L. Zhang, and E. Zhao, Talanta 82 (3), 993 (2010).

9. I. M. Dittert, D. L. G. Borges, B. Welz, A. J. Curtius, and H. Becker-Ross, Microchim. Acta 167 (1), 21 (2009).

10. M. Saber-Tehrani, M. H. Givianrad, and P. Kahkashan, Biol. Trace Element Research 116 (2), 155 (2007).

11. B. Salih, O. Celikbiçak, S. Doker, and M. Dogan, Anal. Chim. Acta 587 (2), 272 (2007).

12. P. R. M. Correia, P.V. Oliveira, J. A. G., Neto, and J.A. Nobrega, J. Anal. At. Spectrom. 19 (7), 917 (2004).

13. A. Matsumoto, T. Nakahara, and Tetsu-To-Hagane, J. of the Iron and Steel Institute of Japan 91 (5), 69 (2005).

14. M. A. Rahman, S. Kaneco, Md. N. Amin, T. Suzuki, and K. Ohta, Talanta 62 (5), 1047 (2004).
15. H. Tavallali and A.M. Attaran, International Journal of Chem. Tech. Research 2 (3), 1724 (2010).

16. I. De Schrijver, M. Aramendia, L. Vincze, M. Resano, A. Dumoulin, and F. Vanhaecke, Spectrochim. Acta - Part B, Atomic Spectroscopy 62 (11), 1185 (2007).

17. J.L Barriada, A.D. Tappin, E.H. Evans, and E.P. Achterberg, TrAC - Trends in Anal. Chem. 26 (8), 809 (2007).

18. A.N Anthemidis, V. Arvanitidis, and J. A. Stratis, Anal. Chim. Acta 537, 271 (2005).

19. P. Cava-Montesinos, M. L. Cervera, A. Pastor, and M. De La Guardia, Anal. Chim. Acta 531, 111 (2005).

20. S.B. Chang and C.L. Chakrabarti, Prog. Analyt. At. Spectrosc. 8, 102 (1985) (and reference therein).

21. Neelam Goyal, P.J. Purohit, A.R. Dhobale, A.G. Page, and M.D. Sastry, Fresenius J. Anal. Chem. 330, 114 (1988).

22. Neelam Goyal, P.J. Purohit, and S. V. Godbole, At. Spectrosc. 31, 195 (2010).

23. Neelam Goyal, Renu Agarwal, Paru J.Purohit, and S. V. Godbole, J. Nucl. Mat. 376, 119 (2008).

24. Santosh Kumar Gupta, Neelam Goyal, and S.V. Godbole, At. Spectrosc. 32, 107 (2011).

25. W. C. Compbell and J. M. Ottaway, Talanta 21, 837 (1974).

26. T.R.G. Kutty, P.V. Hegde, K.B. Khan, T. Jarvis, A.K. Sengupta, S. Majumdar, and H.S. Kamath, J. Nucl. Mat. 335, 462 (2004).

27. B. Hircq, Spec. Chim. Acta, 31B, 153 (1976).

28. H.Y. Xiao, Y. Zhang, and W.J. Weber; J. Nucl. Mat. 414, 464 (2011). 